\title{
Kunsten at tabe et valg
}

\section{Mads Qvortrup}

Alt tegnede til en historisk sejr for de britiske Konservative. I stedet blev det en lektion $i$, hvordan man ikke fører valgkamp, og et personligt nederlag for premierminister Theresa May.

"Nothing has changed - NOTHING has changed". Theresa May lød nærmest grådkvalt, da hun gentog sit svar til BBC-journalist Laura Kuenssberg, som mange ellers elsker at hade på grund af hendes angivelige tendens til ikke at stille hårde spørgsmål til konservative politikere. Men ikke denne dag.

Den skotske journalist havde spurgt, hvorfor regeringen havde foretaget en kovending i spørgsmålet om brugerbetaling for pensionister. Det afviste May - selvom hun få minutter tidligere havde indrømmet det modsatte.

I dette øjeblik, i de få sekunder, den britiske premierminister ytrede netop disse ord havde alt 'ændret sig. Den 22. maj var dagen, hvor de britiske Konservative mistede deres selvsikkerhed; dagen hvor historiens største forspring blev sat over styr; dagen hvor det viste sig, at Theresa Mays slogan om at være 'strong and stable' - stærk og stabil - nærmest var det modsatte.
Som ulve, der lugter blod, kastede de særligt indkaldte journalister sig over premierministeren. Borte var den ærbødighed, som tidligere havde kendetegnet valgkampen.

Michael Crick - fra den kommercielle tv-station ITV (den svarer nogenlunde til TV2) - på det nærmeste dolkede May med spørgsmålet: "Så premierminister, du er ikke så 'stærk og stabil'. Du er mere 'blød og blævrende' (weak and wobbly). Er du ikke?" May svarede ikke. Og hendes udenomssnak druknede i nedladende hånlatter fra den samlede elite af Westminster Lobby Correspondents.

\section{En skæbnesvanger detalje}

Som det så ofte er tilfældet, var det en detalje der ændrede billedet. Få dage forinden havde de Konservative fremsat deres valgprogram. Partiet var på det nærmeste lysår foran Labour. I gennemsnit stod oppositionspartiet til omkring 24 pct. De Konservative stod til næsten det dobbelte. Aldrig tidligere havde et oppositionsparti stået ringere. May havde et større forspring end selv Margaret Thatcher, og mange konservative sammenlignede May med Storbritanniens første kvindelige regeringsleder.

Mads Qvortrup er professor ved Coventry University. Hans bog Government by Referendum udkommer på Manchester University Press i januar 2018. 


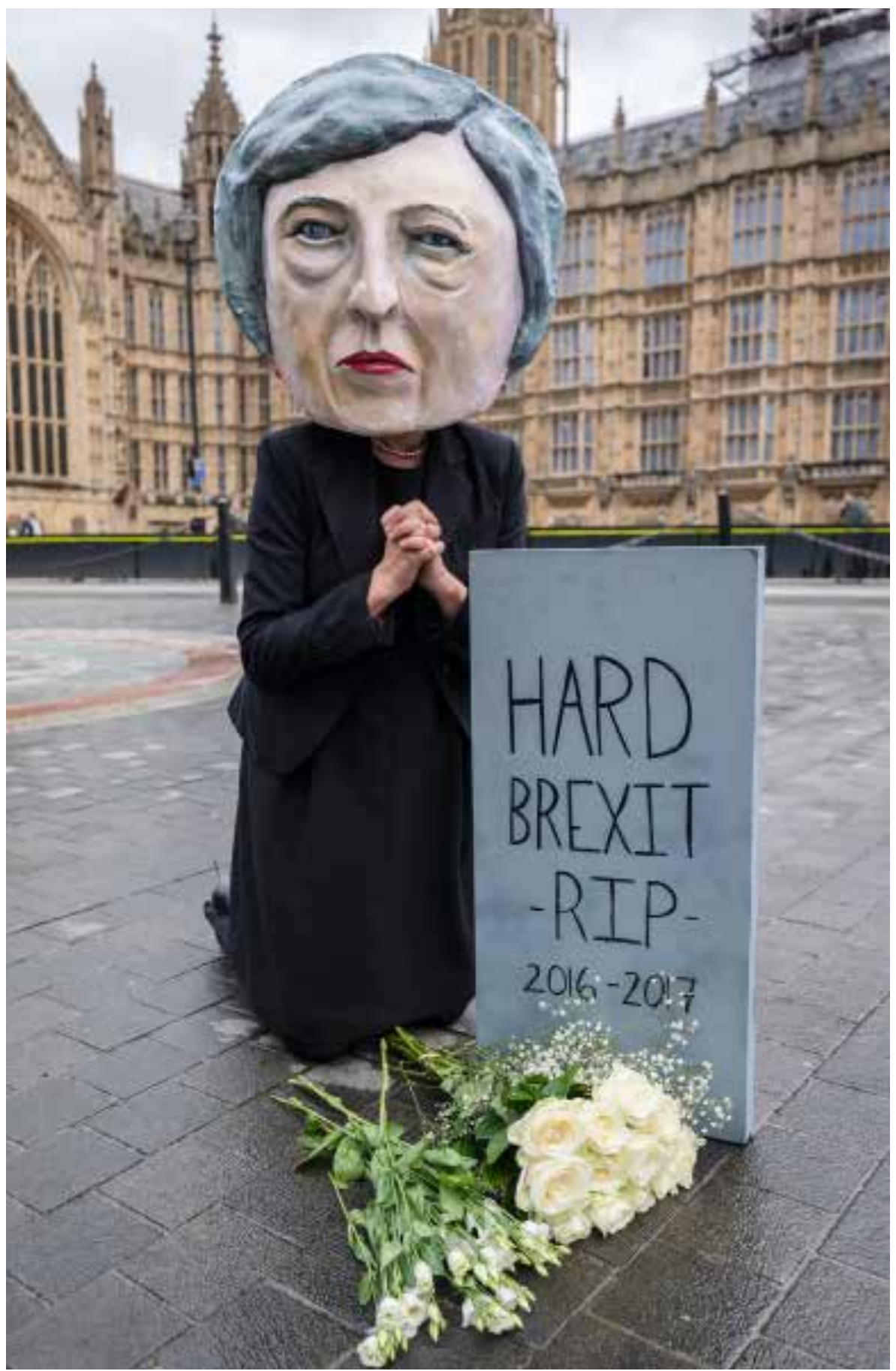


Med et sådant flertal i udsigt kunne de Konservative gennemføre forslag, der ellers ville være politisk selvmorderiske. Det var i hvert fald opfattelsen i Mays inderkreds. Hendes to nærmeste rådgivere - stabschef Nick Timothy og hendes spindoktor Fiona Hill førte pennen. De foreslog, at man indførte brugerbetaling for plejehjemspladser. Hidtil havde ældre ikke selv skullet betale. Men, foreslog de Konservative, i fremtiden skulle de, der havde en bolig med en ejendomsvurdering på over 100.000 pund selv betale.

Men betalingen skulle først falde, når den ældre var død. Det opfattede May og hendes stabschef som progressivt og konservativt. Det viste, mente Nick Timothy, at Tory-partiet ikke ville acceptere, at de rige kom gratis på plejehjem, når de selv havde råd til at betale. $\mathrm{Og}$ så var det i øvrigt god konservativ politik at indføre brugerbetaling.

Theresa May og hendes inderkreds inddrog ikke de andre kabinet medlemmer i disse overvejelser. End ikke finansministeren. Dette var en valgkamp, der fokuserede på, at May var en populær politiker.

Det var en ædruelig disposition - dengang.

\section{Det overraskende valg}

Indtil midten af marts var der ikke mange, der regnede med, at der ville blive udskrevet valg. Brexit-forhandlingerne betød, at man ikke havde tid til at afholde valg, hvis tidsplanen skulle overholdes. Det irriterede mange Konservative, som så Labour-partiets indre kaos som en chance for, måske for altid, at udradere partiet. Labours leder, den 68-årige Jeremy Corbyn, blev af mange vælgere opfattet som en ynkelig hippie. Tabloidpressen hånede den aldrende socialist for at være vegetar, bage fuldkornsbrød og bruge sin fritid i sit kolonihavehus.
Med et program, der mindede mere om Enhedslistens principprogram end Tony Blairs regeringspolitik tidligere i dette årtusinde, forsøgte Corbyn at appellere til yngre vælgere, lavtlønnede og pensionister. Han lovede blandt andet at afskaffe studieafgiften (det koster 9.000 pund per år at gå på universitetet) og at gennationalisere jernbanerne.

Corbyn havde overlevet en mistillidsafstemning blandt de menige medlemmer af Labour, men et flertal af parlamentsgruppen var imod ham. Mange ønskede mere - eller ofte mindre - stiltiende, at Labour tabte valget, så de kunne få en mere midtsøgende leder; en leder der havde en realistisk chance for at vinde et valg.

Mange lederskribenter og tidligere ministre opfordrede Theresa May til at udskrive valg. Premierministeren afviste det flere gange, men så ændrede hun holdning. Den 18. april - efter en ferie i Wales med sin mand - overraskede hun alle. Der skulle nu holdes valg den 8 . juni.

Forfatningsretligt var det ikke muligt for May selv at udskrive valg. Ifølge den såkaldt Fixed-term Parliaments Act 2011 kan man - ligesom i Norge - ikke holde valg i utide. For at udskrive valg inden valgperiodens udløb kræves der et to-tredjedeles flertal i Underhuset.

Teknisk set kunne Labour have forhindret valget. Men Corbyn vidste, at mange parlamentsmedlemmer ønskede et valg. Hvis han afviste, var der en realistisk mulighed for, at mange af Labours parlamentsmedlemmer ville stemme med regeringspartiet og dermed ydmyge ham yderligere. Labour stemte for valget. Kun en håndfuld medlemmer af det skotske nationalparti SNP stemte imod.

Alle meningsmålinger tydede på en historisk sejr for May. Labours hårdprøvede spindoktorer forsøgte sig med sloganet 
'Let June be the end of May'. Meget elegant og opfindsomt, jovist, men også håbløst urealistisk.

Den legendariske kommentator og professor Vernon Bogdanor forudså, at Labour ville tabe flere mandater end i 1983. Dengang havde Margaret Thatcher massakreret Labour. I hine tider var Labour ledet af Michael Foot, en erklæret socialist i slutningen af tresserne, der ønskede at afskaffe atomvåben og nationalisere dele af industrien. At Foot havde en rådgiver, der hed Jeremy Corbyn, og at denne stadig havde de samme synspunkter som sin hedengangne chef, undlod de konservative medier ikke at gøre opmærksom på.

\section{Valgkampen}

Theresa May gjorde det fra starten klart, at hun ville føre en personlig valgkamp; at hun - bemærk entalsformen - søgte et mandat forud for Brexit-forhandlingerne. Hun ville bruge valgkampen på at tale med 'almindelige vælgere, fremfor at debattere med Jeremy Corbyn: "vi diskuterer hver uge i Underhuset".

Det skulle vise sig at være en fejlkalkulation. Det blev snart klart, at May ikke mødtes med almindelige vælgere, men med særligt udvalgte partimedlemmer, der i busser blev kørt ud på fabrikker, når arbejderne var gået hjem. Det var i sig selv lettere pinligt.

Hvad der var ligeså problematisk for May var, at hun på disse 'valgmøder' gentog testede sound bites og forskellige mantra om at 'Brexit means Brexit' - 'I am strong and stable’. Spørgsmål om fremtiden blev besvaret med variationer over dette tema. Og ofte med en bisætning om at hun - Theresa May - havde været en succesfuld indenrigsminister i over seks år.

De trykte og de elektroniske medier rapporterede troskyldigt fra Mays møder.
Men, med skyldigt hensyn til kravet om balance og det gamle engelske princip om 'fair play' rapporterede de også fra Jeremy Corbyns mere improviserede valgmøder.

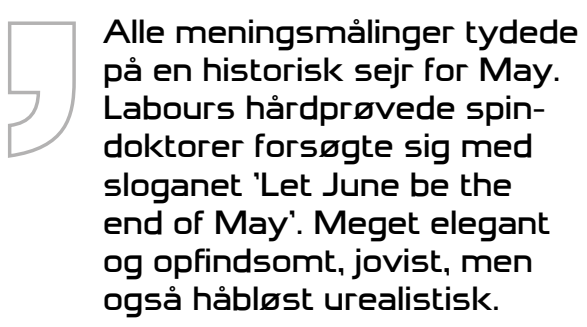

Den aldrende socialist førte en valgkamp inspireret af Bernie Sanders i USA. Han talte dunder til de rige, de multinationale selskaber og de Konservative. Hans taler var ikke retorisk formfuldendte, men hans lidenskabelige stil og løfter om bedre forhold for studerende og lavtlønnede gjorde indtryk på disse vælgersegmenter, og hans fans tiljublede ham som en rockstjerne.

Corbyns popularitet spredte sig som en steppebrand på de sociale medier, hvor spontane grupper af studenter opfordrede unge til at skrive sig på valglisterne. Mange er ikke valgberettigede, da de som studerende bor uden for deres forældres valgkreds, og da der ikke er automatisk vælgerregistrering i Storbritannien, betyder det, at yngre systematisk er underrepræsenterede.

Denne folkebevægelse blev mest af alt opfattet som et kuriosum i de traditionelle medier. Alle regnede med, at May ville vinde. Og vinde stort. Denne opfattelse blev bekræftet da de Konservative i begyndelsen af maj vandt en række lokalvalg. Labour tabte - og tabte markant. Overordnet set vandt de Konservative 38 pct. - Labour fik kun opbakning af sølle 27 pct. af vælgerne.

At de Konservative vandt West Midlands - omkring Birmingham, hvor Labour traditionelt står stærkt - blev opfattet som et tegn på, at Theresa May appellere- 
de til 'almindelige' arbejdervælgere. At det EU-skeptiske United Kingdom Independence Party (UKIP) tabte alle de pladser ,de havde i by- og amtsråd, blev også opfattet som et godt tegn for Theresa May.

\section{Valgprogrammerne}

Da Labour en uge senere præsenterede deres valgprogram, var opfattelsen, at slaget var tabt på forhånd. Selvom Corbyn og hans skyggefinansminister John McDonald fremlagde detaljerede beregninger af, hvad deres valgløfter ville koste, kritiserede de Konservative Labour for at gøre regning uden vært.

Men da Theresa May - og igen er entalsformen bevidst! - afviste at fremlægge konsekvensberegninger for, hvad det Konservative program ville koste, undgik det ikke mediernes opmærksomhed. Medierne undlod heller ikke at bemærke, at de Konservative - eller rettere Mays spindoktorer - ville indføre delvis brugerbetaling på plejehjemspladser.

Jeremy Corbyn kaldte det en 'demens-skat' (dementure tax). At ældre, der var demente og ikke kunne forblive i eget hjem, var tvunget til at betale, blev opfattet som uretfærdigt.

May var ikke umiddelbart opmærksom på faren. Igen undervurderede de Konservative Labour. Premierministeren sagde som instrueret af hendes spindoktorer - at det var en ansvarlig politik, at de rige skulle betale til det fælles vel. Som nævnt skulle man kun betale, hvis man havde et hus eller opsparing på over 100.000 pund. Men da huspriserne i Storbritannien - især i London - er høje, betød det, at over 80 pct. af alle husejere nu skulle betale for en plejehjemsplads. At denne betaling først skulle falde, når den ældre var død, betød at forslaget reelt var en ny arveafgift og en ekstraudgift for dem, der ikke var rige.
Da selv nøje udvalgte vælgere, som Theresa May kom i kontakt med, kritiserede forslaget - og gjorde det for rullende kameraer - skabte det panik i Conservative Central Office. Kun tre dage efter, at programmet var fremsat, blæste May retræte. Om end hun fastholdt stædigt, at 'Nothing has changed'.

"Jeg har skrevet om og rapporteret alle valg siden 1945, men jeg har aldrig set noget lignende", sagde Sir David Butler, den legendariske 93-årige valgforsker og tv-kommentator, til BBC.

Fra dette øjeblik gik det ned ad bakke for May.

\section{Terrorangrebet}

Tilbage i 1950'erne blev daværende premierminister, den konservative Harold Macmillan, spurgt, hvad der var hans største udfordring. Den aristokratiske statsmand svarede: "Events, dear boy, events". Med andre ord: alle de store og små uforudsigelige tilfælde, der sker hele tiden.

Det var en stort 'event' der skete den 22. maj. Umiddelbart efter en koncert med popstjernen Ariana Grande eksploderede en bombe i Manchester Arena. Bomben dræbte 23 .

Alle parter fordømte angrebet, og ingen politikere stillede op til et interview på BBC's Today Program morgenen efter. Der skulle ikke slås politisk mønt på angrebet.

Og alligevel fik ugerningen politiske konsekvenser. I et interview med en menig betjent, sagde politimanden, at dette ikke ville være sket, hvis der ikke havde været drastiske nedskæringer i antallet af ansatte i politiet.

Det gik hurtigt op for mange, hvem der var ansvarlig for disse nedskæringer. Avisen The Guardian - der politisk er lettere til venstre for midten - søgte aktindsigt 
fra Indenrigsministeriet. Tallene bekræftede, at antallet af gadebetjente var faldet med hele femten pct.

Theresa May havde baseret sine lederevner på sin 'succes' som indenrigsminister og ikke mindst på sin håndfaste kurs over for The Police Federation (de menige betjentes fagforening). Terrorangrebet i Manchester forstærkede yderligere indtrykket af Theresa May som alt andet end stålsat.

Denne overraskende åbning blev udnyttet af Jeremy Corbyn. Det var paradoksalt. Han havde stemt imod stramninger af terrorlovgivningen, havde tidligere ytret forståelse for IRA i Nordirland og havde været en af de fremmeste repræsentanter for fredsbevægelsen. Under normale omstændigheder ville et sådant politisk generalieblad være en gave for de Konservative: et parti, der ligesom i Danmark gerne fremstiller sig som 'lov og orden'-partiet.

\section{$\square$ At krigen i Irak og senere indsatsen i Syrien havde gjort Storbritannien til et mål for islamistisk terrorisme, blev af mange opfattet som en selvfølgelighed}

De konservative spindoktorer var da også begejstrede, da Corbyn kort efter terrorangrebet sagde, at den britiske regerings udenrigspolitik - især i Mellemøsten - var en af grundene til at britiske muslimer var blevet radikaliserede. Theresa May brugte denne anledning til et frontalangreb på Labour-lederen. Hun beskyldte Corbyn for at være blødsøden og farlig for Storbritanniens sikkerhed. Men da hun igen blev konfronteret med nedskæringerne, mens hun var minister, svarede hun vagt og gav igen indtryk af at være vaklende: alt andet end strong and stable.
Problemet for May - og de Konservative - var, at Corbyns synspunkt blev delt af mange, der ellers ikke stemte Labour. At krigen i Irak og senere indsatsen i Syrien havde gjort Storbritannien til et mål for islamistisk terrorisme, blev af mange opfattet som en selvfølgelighed. Angrebet på Corbyn prellede af, og meningsmålinger tydede på, at Labour klarede sig bedre, end nogen havde forudset. Tre uger inden valget stod partiet til 32 pct. En fremgang på otte pct., men stadig elleve pct. bagud $\mathrm{i}$ forhold til de Konservative.

Det bekymrede ikke de Konservative. Det skulle det have gjort. Regeringspartiets private meningsmålinger viste, at partiet kunne hente stemmer i Skotland. Lokalvalgene tydede samtidigt på, at Mays parti kunne hente stemmer i traditionelle arbejderkvarterer. Mange Labour vælgere havde stemt på UKIP, men efter folkeafstemningen om Brexit håbede de Konservative, at de kunne lokke disse til at stemme på et mere socialt konservativt parti.

Men med Corbyns valgløfter om højere mindsteløn og afskaffelse af studieafgiften og ved ikke at sige noget om Brexit var det svært for de Konservative at fremstille deres program som socialt ansvarligt. Den katastrofale håndtering af 'demensskatten' og Theresa Mays stadig stigende usikkerhed og manglende selvsikkerhed hjalp ikke partiet.

\section{Corbyn og middelklassen}

Samtidigt begyndte mange middelklassevælgere at se mere positivt på Corbyn. Begge partiledere var inviteret i studiet for at tale om dem selv på det journalistisk set letbenede program The One Show.

May mødte op med sin mand Philip (der er millionær og underdirektør i en investeringsbank). Gemalen virkede af- 
slappet, men May virkede stiv, nervøs og kunne ikke snakke om almindeligheder. Corbyn tog ikke sin kone med. Klædt som en pensionsmoden geografilærer talte han om at bage brød, om sit kolonihavehus og om, at alle burde have ret til at dyrke grønsager. Manden som The Sun kaldte 'an extreme Marxist' - en yderliggående marxist - virkede som en almindelig mand fra middelklassen. Meningsmålingerne viste 35 pct. for Labour. Men med kun to uger inden valget, var der ikke mange der troede på Corbyns chancer.

To dage inden valget var der endnu et terroranslag. Denne gang i London. Otte mennesker blev dræbt. Tal fra Londons lokalstyre viste, at nedskæringerne i politistyrken $i$ byen var højere end $i$ andre dele af landet.

At disse tal var produceret af Londons borgmester, Labours Sadiq Khan - den eneste borgmester i en europæisk hovedstad, der er muslim - blev ikke bemærket. Kildekritik er ikke altid mediernes stærke side. Måske var det derfor, at May - igen kom dårligt ud af angrebet.

Men trods dette førte de Konservative stadig komfortabelt. Men forspringet var skrumpet ind, og nogle begyndte at tale om et hung parliament (et parlament, hvor intet parti har absolut flertal). De Konservative advarede imod en 'kaoskoalition' hvis Corbyn, de Skotske Nationalister og de Grønne tilsammen vandt et flertal. Men det blev ikke helt taget alvorligt.

\section{Historisk resultat}

Klokken 22:01 den 8. juni kom den første prognose: De Konservative havde tabt det absolutte flertal, som de havde vundet under David Cameron i 2015. Labour var kun et par procentpoint bagefter. Det valg, som May havde udskrevet for at sikre et mandat forud for Brexit-forhandlingerne, var ikke endt i en sejr.

Corbyn - en traditionel socialist der talte om nationaliseringer - havde sikret sit parti knap 42 pct. af stemmerne. Det var mere end Tony Blair i 2001.

Var det et katastrofalt nederlag for May? Var det en sejr for Corbyn?

Der kunne ikke være tvivl om, at sidstnævnte havde overrasket selv sine mest optimistiske tilhængere. At vinde knap 20 pct. i løbet af en valgkamp er historisk.

Men Corbyn vandt ikke valget. De Konservative var stadig det største parti. Og, ikke nok med det. Theresa Mays parti havde, med 44 pct. af stemmerne, overgået Margaret Thatchers højdepunkt på 43 procent i 1983. Det sidste blev fremført af Mays spindoktorer. Men ikke mange var overbeviste. Labour vandt, om end efter fintælling, Chelsea and Kensington. Det svarer til, at Enhedslisten vinder Frederiksberg.

Hvad skyldtes det overraskende resultat? Historisk set var valget et tegn på en normalisering. Traditionelt set har det britiske politiske system været et to-parti system. Denne tendens var formindsket, efter at Liberal Demokraterne, de Skotske Nationalister (SNP) og andre partier var kommet i Parlamentet.

At de Konservative trods alt vandt 44 pct. af stemmerne skyldtes, at partiet vandt stemmer fra UKIP. Sidstnævnte havde vundet knap fire mio. stemmer ved valget i 2015, men havde ikke vundet pladser i parlamentet. Ved valget i 2017 fik partiet kun 500.000 stemmer. Labour scorede på, at mange tidligere liberale og skotske nationalister stemte på dem. Labour høstede samtidig gevinsten af, at mange unge stemte. Omkring 70 pct. af vælgerne under tredive stemte på et parti, hvis leder er næsten halvfjerds. 
May havde udskrevet valget med ét eksplicit mål: at få et mandat til Brexit-forhandlingerne. Det havde hun ikke fået. Med hendes egne alen havde hun tabt. Det viste hun ikke, da hun den 9. juni om formiddagen tog til Dronningen. Og May var heller ikke til sinds at indrømme nederlaget, da hun oplæste en kort besked til pressen uden for Downing Street 10. Hun konstaterede at de Konservative var det største parti, og at hun ville fortsætte. Hun besvarede ingen spørgsmål.

\section{The Economist - det ansete ugemagasin - forudser at briterne forlader det Indre Marked, at Corbyn bliver premierminister, og at hans erklærede socialistiske politik vil få endnu flere virk- somheder til at forlade det Forenede Kongerige.}

Da hun blev kritiseret for den kaotiske valgkamp, fyrede hun sine spindoktorer og sagde, at hun i fremtiden ville lytte mere til sine kabinetkollegaer. Det skabte ro - i hvert fald for en tid. Ingen af de andre konservative ønskede umiddelbart at udfordre hende. De to ledende kandidater, udenrigsminister Boris Johnson og indenrigsminister Amber Rudd, havde fået et dårligt valg $\mathrm{i}$ deres respektive valgkredse. Sidstnævnte havde kun vundet sit mandat efter en fintælling.

I de følgende dage forsøgte Labour at sammentømre en alternativ koalition. Men de ideologiske skel mellem oppositionspartierne var for store. Theresa May derimod var mere heldig. Hun inviterede The Democratic Unionists - et højreorienteret, Brexit-venligt, og frem for alt kristent fundamentalistisk nordirsk par- ti til forhandlinger om et formelt samarbejde. Partiet - der er imod abort, homofile vielser og EU - indgik efter adskillige indrømmelser og finansielle incitamenter en toårig aftale om at være støtteparti for May. Den aftale kostede May ti mia. pund.

Corbyn kaldte lakonisk aftalen for 'en kaos-koalition'.

Kort efter May var kommet tilbage, genoptog eller rettere begyndte man forhandlingerne om Brexit. Det var paradoksalt et emne, som næsten ikke var diskuteret under valgkampen. Meningsmålingerne tydede - og tyder - på, at endnu flere ville stemme for udtræden af EU, hvis der igen blev holdt en folkeafstemning. Store banker og forsikringsselskaber annoncerede, at de ville forlade London.

To måneder efter valget viste opinionsmålingerne, at Corbyn ville slå May, hvis der igen var valg. Det var - paradoksalt nok - en positiv besked for premierministeren. Udsigterne til at de Konservative ville tabe et parlamentsvalg, overbeviste hendes rivaler om ikke at afsætte hende. Men hun lever i bedste fald på lånt tid.

Og hvad nu? The Economist - det ansete ugemagasin - forudser at briterne forlader det Indre Marked, at Corbyn bliver premierminister, og at hans erklærede socialistiske politik vil få endnu flere virksomheder til at forlade det Forenede Kongerige. Inden Storbritannien kom med i EU, kaldte samme publikation landet for Europas syge mand. Dengang var man skeptisk over for protektionisme og bekymret over Labours forsmag for planøkonomi og nationaliseringer.

Hvis pessimisterne har ret, vil The United Kingdom igen indtage pladsen som Europas syge mand. 


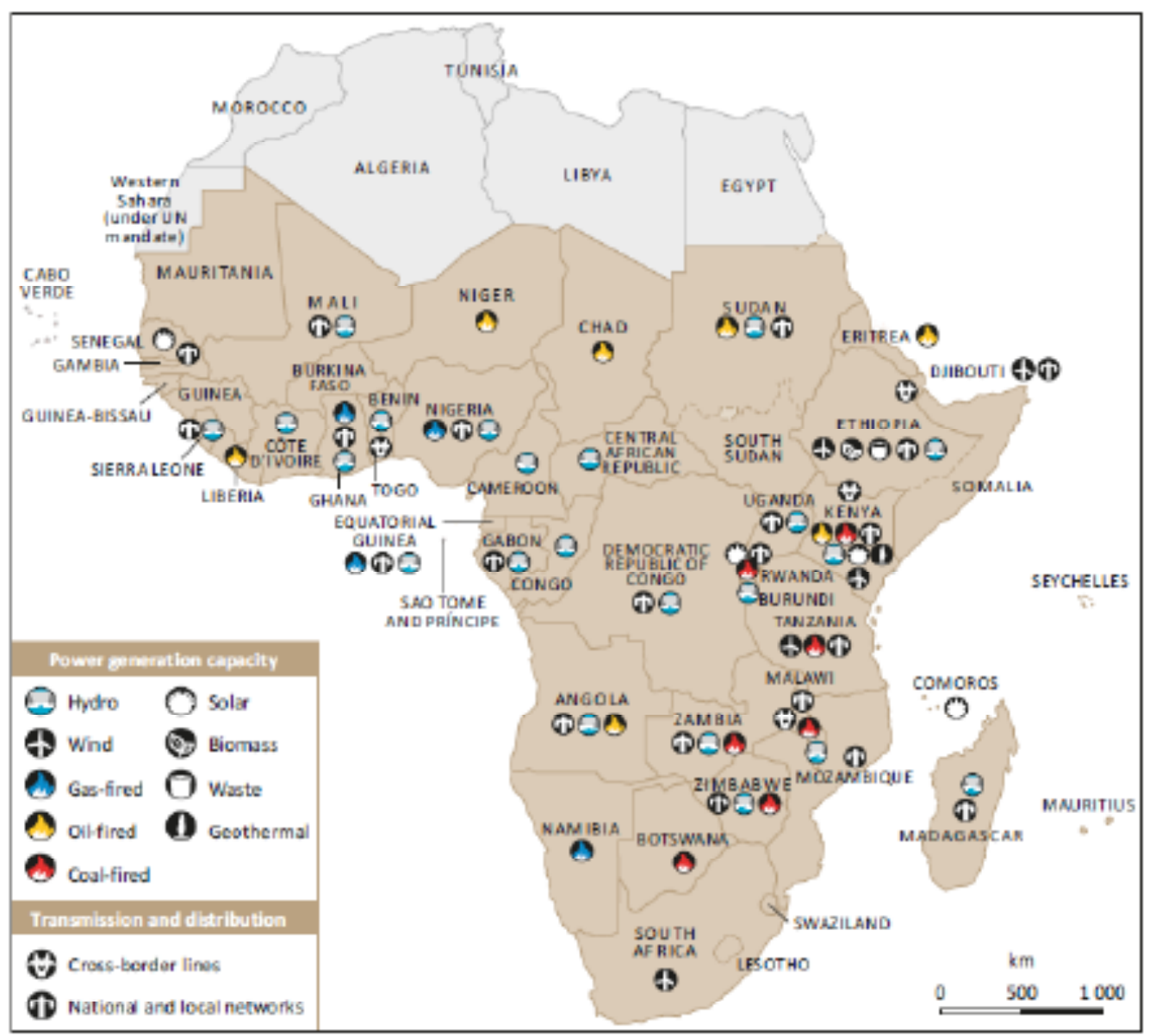

KILDE: OECD, 2016: "Boosting the Power Sector in Sub-Saharan Africa: China's Involvement", s. 13.

Kinesiske energiprojekter i Afrika: opførte eller planlagte anlæg i perioden 2010-2020 